\author{
$15-17$ February, 2019 in Rom e-Italy
}

\title{
Institutional Reforms, Market Structure and Debt Market Development: Evidence from Israel
}

\author{
Elroi Hadad \\ Holon Institute of Technology (H.I.T)
}

\begin{abstract}
This paper focuses on the impacts of pension funds and market structure on debt market development. We show evidences of major developments of the Israeli government and corporate bonds market depth and liquidity, which found to be associated to gradual changes in the Israeli financial system. These changes include ongoing reforms in the structure of the local debt market, changes in the structure of pension funds savings and changes in the activity of institutional investments regulations, which have boosted local savings and promoted to the debt market development. The Israeli case suggest that policy makers in countries with low debt market development should strive for better regulation in pension funds savings and in market structure in order to promote debt market efficiency.
\end{abstract}

Keywords: Pension Funds Savings; Debt Market Development; Market efficiency; Investment Regulation; Market Structure. 